and a decreased risk of reoperation in this study, recent ex vivo study and several clinical series showed a superiority of straight graft over Valsalva graft. ${ }^{6}$ All these technical factors that may affect the long-term outcomes after VSARR requires further clarification in the future studies.

VSARR, as will be agreed by all cardiac surgeons, is a technically challenging procedure with a steep learning curve even for expert surgeons. Notably, 15 different surgeons contributed to the cohort in this study, which is a quite large number for a single-center experience. Although the authors stated that there was no difference in the operative results among surgeons regardless of the level of experience, it can be conceivable that the cases in this study included those performed by various surgeons over learning curve period. This may partly account for the discrepancies in the outcomes from other studies performed by a minimum of surgeons. ${ }^{2,3}$ However, this study may better reflect real-world outcomes that cardiac surgeons who consider VASRR as a surgical option in their practice may better reference. To spare or not to spare is not clearly the question for the patients with normal leaflet cusps, particularly when performed by expert surgeons with profound experiences. However, for those who are deemed at high risk for failure, endeavors should be continued to broaden the boundaries of VSARR by carefully selecting the patients and optimizing the outcomes with quests on appropriate techniques and graft choices.

\section{References}

1. Patlolla SH, Saran N, Dearani JA, Stulak JM, Schaff HV, Greason KL, et al. Outcomes and risk factors of late failure of valve-sparing aortic root replacement. $J$ Thorac Cardiovasc Surg. 2022;164:493-501.e1.

2. Mastrobuoni S, de Kerchove L, Navarra E, Watremez C, Vancraeynest D, Rubay J, et al. Long-term experience with valve-sparing reimplantation technique for the treatment of aortic aneurysm and aortic regurgitation. J Thorac Cardiovasc Surg. 2019;158:14-23

3. David TE, David CM, Feindel CM, Manlhiot C. Reimplantation of the aortic valve at 20 years. J Thorac Cardiovasc Surg. 2017;153:232-8.

4. David TE, David CM, Ouzounian M, Feindel CM, Lafreniere-Roula M. A progress report on reimplantation of the aortic valve. J Thorac Cardiovasc Surg. September 4, 2020 [Epub ahead of print].

5. Lenoir M, Maesen B, Stevens LM, Cartier R, Demers P, Poirier N, et al. Reimplantation versus remodelling with ring annuloplasty: comparison of mid-term outcomes after valve-sparing aortic root replacement. Eur J Cardiothorac Surg. 2018;54:48-54.

6. Paulsen MJ, Kasinpila P, Imbrie-Moore AM, Wang H, Hironaka CE, Koyano TK et al. Modeling conduit choice for valve-sparing aortic root replacement on biomechanics with a 3-dimensional-printed heart simulator. J Thorac Cardiovasc Surg. 2019; 158:392-403.

\title{
Commentary: Studying the art of mastery, or judgment over technique
}

\section{Dawn S. Hui, MD, and John H. Calhoon, MD}

Perhaps the trait by which surgeons are most judged is that of technical skill. This stance is reflected in quotes such as "A chance to cut is a chance to cure." In later days, these skills have expanded to the use of new approaches and devices. In his 2013 Presidential Address, Dr Hartzell Schaff gave us insight into his view, stating this his "posture [is] not

\footnotetext{
From the Department of Cardiothoracic Surgery, University of Texas Health Science Center at San Antonio, San Antonio, Tex.

Disclosures: The authors reported no conflicts of interest.

The Journal policy requires editors and reviewers to disclose conflicts of interest and to decline handling or reviewing manuscripts for which they may have a conflict of interest. The editors and reviewers of this article have no conflicts of interest.

Received for publication Oct 4, 2020; revisions received Oct 4, 2020; accepted for publication Oct 6, 2020; available ahead of print Oct 13, 2020.

Address for reprints: Dawn S. Hui, MD, Department of Cardiothoracic Surgery, University of Texas Health Science Center at San Antonio, 7703 Floyd Curl Dr, San Antonio, TX 78258 (E-mail: huid@uthscsa.edu).

J Thorac Cardiovasc Surg 2022;164:503-4

0022-5223/\$36.00

Copyright (c) 2020 by The American Association for Thoracic Surgery

https://doi.org/10.1016/j.jtcvs.2020.10.016
}

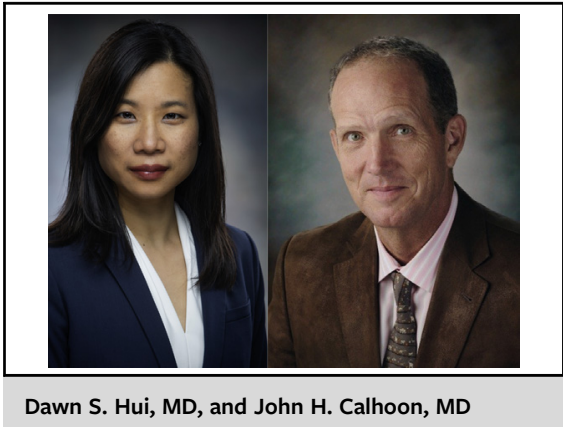

CENTRAL MESSAGE

A large series on valve-sparing aortic root replacement substantiates the importance of experience and refinement in technique over time to achieve excellent long-term outcomes.

to lead by doing necessarily every new operation or using every new device, but to use judgment when implementing new techniques." 1 
In a report by Patlolla and colleagues, ${ }^{2}$ we can perhaps appreciate the fruits of this approach. Their retrospective study examined nearly 25 years' experience of valvesparing aortic root replacement (VSARR). With excellent immediate outcomes, the authors strove to examine risk factors for late valve failure. This is of paramount importance, as patients with proximal aneurysmal disease are typically young (mean age 47.8 years in this series) and with otherwise few comorbidities. The authors found that over the study period, significant improvements were seen in operative mortality, residual aortic regurgitation at discharge, and overall survival. They examined factors that continue to be discussed in aortic root surgery - choice of technique (reimplantation vs remodeling), straight versus sinus grafts, leaflet pathology that requires repair techniques, and bicuspid valve morphology. Multivariable analysis showed that none of these variables were associated with long-term valve failure. Aside from severe annular dilation, only institutional experience over time (and not individual surgeon experience) was associated with improved outcomes. The study was somewhat limited by lack of echocardiographic follow-up, with only one-third of patients having evaluation of valve function beyond 5 years. Furthermore, only $10 \%$ (or 34 patients) underwent the remodeling technique, and over time the authors' preference shifted from a straight graft toward a sinus graft. Although statistical analysis did not find a difference by technique or graft type, the strong institutional preference must surely lend some insight into the authors' judgment of how these elements influence outcomes.

While the authors stress the technical demands and steep learning curve of VSARR, it is the subtle and unquantifiable judgments of how best to deal with early fibrotic changes, structural cusp abnormalities, and the complex geometric and functional relationships of the aortic root components that remain elusive and at the heart of surgical judgment. These variables are unlikely to be ever captured or analyzed even by the most sophisticated statistical techniques. In a previous commentary, Miller $^{3}$ elegantly articulated the evolution of VSARR and the history of numerous variations and modifications of this operation. He identified the importance of "seasoned surgical judgment." While the paper of Patlolla and colleagues is a "study" in the traditional academic sense, it is also a study in the art of mastery and judgment, rather than technique.

\section{References}

1. Moon MR. In the Words of the Presidents. Beverly, MA: American Association for Thoracic Surgery; 2017.

2. Patlolla SH, Saran N, Dearani JA, Stulak HM, Schaff HV, Greason KL, et al. Outcomes and risk factors of late failure of valve-sparing aortic root replacement. J Thorac Cardiovasc Surg. 2022;164:493-501.e1.

3. Miller DC. Valve-sparing aortic root replacement in patients with the Marfan syndrome. J Thorac Cardiovasc Surg. 2003;125:773-8. 